\title{
The Risk Evaluation Research of Computer Network Security based on Grey Clustering
}

\author{
Ning Yu \\ Weifang University of Science and Technology, Weifang, Shandong, CHINA \\ E-mail:7087370@qq.com
}

\begin{abstract}
With the rapid development of science and technology and the network popularization, computer network security becomes a social problem. Based on the analysis of the main factors influencing the computer network security, the risk evaluation index system of computer network security is established. The analytic hierarchy process (AHP) is used to calculate the weight of each index. Through the common criteria to determine the grey clustering of computer network security risk, establishing the whitenization weight function of computer network security risk evaluation model, and then calculating the whitenization clustering coefficient and clustering vector of computer network security risk evaluation model, the evaluation results are finally obtained. The method is scientific and reasonable, combining subjective evaluation with objective calculation.
\end{abstract}

Keywords: Computer network; Grey clustering; Grey class; Evaluation; Weight

\section{Introduction}

Along with the development of Internet technology, computer network has been extended to various industries. Computer network security causes more and more attention to our society. Computer network makes people enjoy information resources sharing, at the same time, it also faces the risk of information security. Information resources sharing and information security is a pair of contradiction. The generality of information and the universality that information is vulnerable to be attacked are two sides in one body. However, the information network of which the main job is carrying and transferring information with its characteristics of no supervisors, cross-border, no defense and lack of legal constraints and etc. brings benefits to people and also huge risk, especially for the demanding application environment such as government organizations. There is a big security risk.

The primary goal of network information security is to make effective security strategy and plans. As people's increasing attention to network security, the first thing that needs to solve is how to evaluate network security. The comprehensive evaluation of network security is an important technology and index of network security defense, which is also an important component of information security engineering. The risk evaluation of computer network security is very complicated, which is a system engineering of multiobjective and multi-index evaluation. The indexes of evaluation engineering have quantitative evaluation indexes and also immeasurable qualitative evaluation indexes. Therefore, the evaluation engineering is greatly influenced by people or experts' value, different people have different evaluation criteria, and the final evaluation results may differ as well.

There are many researches on computer network security risk at home and abroad, most of them are technical researches. There are 7017 results as the key words of computer network security risk in How-net. Wei Yong and Mei HaiBin presented the network security situation evaluation using D - S evidence theory to fuse the information of multiple data sources (IDS). And Jianwei Zhuge used D - S evidence theory to test the 
network anomaly, which belongs to the IDS research. However, there are a few researches on computer network security risk evaluation, and even less these evaluation models.

\section{The Risk Evaluation Index System of Computer Network Security}

\subsection{The Influencing Factor Analysis of Computer Network Security Risk}

In the process of movement and information sharing, there are many risk factors of computer network. It could be concluded that computer network hardware, computer network system, the transmission process of computer network, the system and policy of computer network safety, computer network security technology and some other aspects. Synthesizing all factors affecting computer network safety, the risk factors affecting computer network security could be divided into four categories, that is, the physical factors of computer network security, the system factors of computer network security, the technology factors of computer network security, and the communications security factors of computer network.

\section{(1) The Physical Factors of Computer Network Security}

The first thing affecting computer network security is the network environment and the quality of computer network hardware. Moist environment could affect network transmission and network facility lifetime. Static electricity can cause the unsmooth phenomenon of network or damaging computer network facilities. Vibration or lightning can have a great influence on the computer network. Therefore, in the process of evaluation, the physical factors of computer network security could not be neglected.

(2) The System Factors of Computer Network Security

The risk evaluation of computer network security must be combined with the national regulations and system.

Only the strict abidance of the national computer network security system could ensure the security of computer network. Therefore, the improvement of the national computer network security system is also an important index of computer network security evaluation. Under its system, network management personnel should be needed. Set up the computer network security module, and make the emergency plan of computer network security.

\section{(3) The Technology Factors of Computer Network Security}

Computer network security technology is the highest priority of computer network security, which is an important means to ensure the safety of computer network. Computer network security technology is influenced and restricted by network management personnel's knowledge and skills, the technology of computer system security, the security rank of computer firewall, the technology of computer automatic scanning loopholes, and the automatic detection technology of computer intrusion.

(4) The Communications Security Factors of Computer Network

In the process of computer network communications, it could have the risk of interception. Therefore, it is requested to guarantee the safety of computer network communications facilities, keep computer network communications lines unblocked, and transmit the confidential information using encryption. At the same time, the emergency plans of computer network communications should be made. 


\subsection{Construct the Risk Evaluation Index System of Computer Network Security}

On the premise of comprehensive analysis and recognition on the influencing factors of computer network security, combined with the opinion of computer network security experts, the risk evaluation index system of computer network security is finally determined. The specific details are shown in Table 1.

\section{Table 1. The Evaluation Index System of Computer Network Security}

\begin{tabular}{|c|c|c|}
\hline The target layer & The criteria layer (risk source) & The index layer \\
\hline \multirow{4}{*}{$\begin{array}{c}\text { The evaluation } \\
\text { index system of } \\
\text { computer } \\
\text { network } \\
\text { security P }\end{array}$} & $\begin{array}{c}\text { Physical security of computer } \\
\text { network } \\
\mathrm{P}_{1}\end{array}$ & $\begin{array}{l}\text { (1)The environment security of } \\
\text { computer network } \mathrm{P}_{11} ; \\
\text { (2)The hardware quality of } \\
\text { computer network } \mathrm{P}_{12} ; \\
\text { (3)computer network equipment } \mathrm{P}_{13} \\
\text {; } \\
\text { (4)computer network monitoring } \mathrm{P}_{14} \\
\text {; } \\
\text { (5)computer network stability } \mathrm{P}_{15} \text {; }\end{array}$ \\
\hline & $\begin{array}{c}\text { Security system of computer } \\
\text { network } \mathrm{P}_{2}\end{array}$ & $\begin{array}{l}\text { (1)The management system of } \\
\text { computer network } \mathrm{P}_{21} ; \\
\text { (2)The personnel allocation of } \\
\text { computer network } \mathrm{P}_{22} \\
\text { (3)The hierachical system of } \\
\text { computer network } \mathrm{P}_{23} ; \\
\text { (4)Accident treatment plan of } \\
\text { computer network } \mathrm{P}_{24} ; \\
\text { (5)Module setting of computer } \\
\text { network security } \mathrm{P}_{25}\end{array}$ \\
\hline & $\begin{array}{c}\text { security technology of computer } \\
\text { network } \\
\mathrm{P}_{3}\end{array}$ & $\begin{array}{l}\text { (1)management personnel of } \\
\text { computer network } \mathrm{P}_{31} \\
\text { (2)The security technology of } \\
\text { computer system } \mathrm{P}_{32} ; \\
\text { (3)computer firewall setting } \mathrm{P}_{33} \text {; } \\
\text { (4)computer vulnerability scanning } \\
\mathrm{P}_{34} \text {; } \\
\text { (5)computer intrusion detection } \mathrm{P}_{35} \\
\text {; }\end{array}$ \\
\hline & $\begin{array}{l}\text { The communication security of } \\
\text { computer network } \\
\qquad \mathrm{P}_{4}\end{array}$ & $\begin{array}{l}\text { (1)communications facility security } \\
\text { of computer network } \mathrm{P}_{41} ; \\
\text { (2)communications line security of } \\
\text { computer network } \mathrm{P}_{42} ; \\
\text { (3)communication encryption } \\
\text { measures of computer network } \mathrm{P}_{43} \\
; \\
\text { (4)communication control measures } \\
\text { of computer networkP } \mathrm{P}_{44} ; \\
\text { (5)communications emergency } \\
\text { measures of computer network } \mathrm{P}_{45} \\
;\end{array}$ \\
\hline
\end{tabular}




\section{Establish Computer Network Security Risk Evaluation Model of Grey Clustering}

\subsection{Calculate and Determine Each Risk Evaluation Index Weight Coefficient of Computer Network Security.}

In computer network security risk evaluation model of grey clustering, aiming at constructing the risk evaluation index system of computer network security, the analytic hierarchy process (AHP) is used to determine and calculate the weight of each evaluation index.

First of all, construct the hierarchical structure diagram of computer network security risk. The details are shown in diagram 1: the target layer is $\mathrm{P}$, the factor set of criteria layer is $\left(\mathrm{P}_{1}, \mathrm{P}_{2}, \mathrm{P}_{3}, \mathrm{P}_{4}\right)$, the second-level index evaluation $\operatorname{set}\left(\mathrm{P}_{11}, \mathrm{P}_{12}, \mathrm{P}_{13}, \mathrm{P}_{14}, \mathrm{P}_{15}, \mathrm{P}_{21}, \mathrm{P}_{22}, \mathrm{P}_{23}, \mathrm{P}_{24}, \mathrm{P}_{25}, \mathrm{P}_{31}, \mathrm{P}_{32}, \mathrm{P}_{33}, \mathrm{P}_{34}, \mathrm{P}_{35}, \mathrm{P}_{41}, \mathrm{P}_{42}, \mathrm{P}_{43}, \mathrm{P}_{44}, \mathrm{P}_{45}\right)$, the decision layer.

Then, the expert evaluation method is used to construct each index multiple comparison matrix of computer network security risk at all levels. Use program MATLAB to calculate the weight of each evaluation index, and make sure that the results could pass the consistency check. The risk evaluation index weight of computer network security is shown in Table 2.

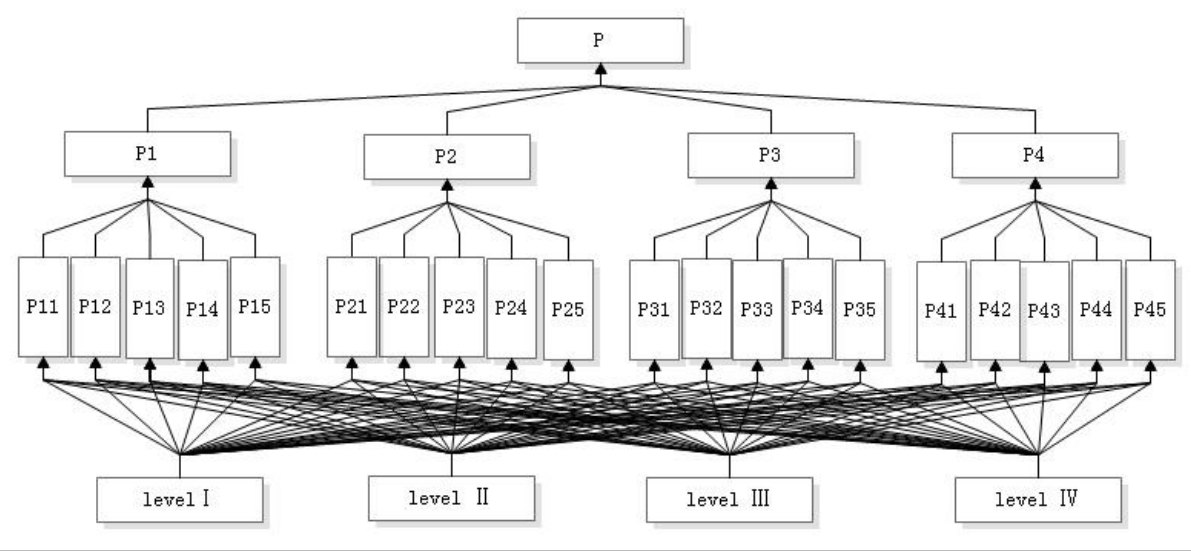

Diagram 1. The Hierarchical Structure Diagram of Computer Network Security Risk

Table 2. The Risk Evaluation Index Weight of Computer Network Security

\begin{tabular}{|c|c|c|c|c|c|}
\hline \multirow{2}{*}{ index } & $\mathrm{P}_{1}$ & $\mathrm{P}_{2}$ & $\mathrm{P}_{3}$ & $\mathrm{P}_{4}$ & weight \\
& 0.107 & 0.049 & 0.595 & 0.249 & $W_{i}$ \\
\hline $\mathrm{P}_{11}$ & 0.427 & & & & 0.046 \\
\hline $\mathrm{P}_{12}$ & 0.061 & & & & 0.007 \\
\hline $\mathrm{P}_{13}$ & 0.146 & & & & 0.016 \\
\hline $\mathrm{P}_{14}$ & 0.096 & & & & 0.010 \\
\hline $\mathrm{P}_{15}$ & 0.271 & & & & 0.029 \\
\hline $\mathrm{P}_{21}$ & & 0.056 & & & 0.003 \\
\hline $\mathrm{P}_{22}$ & & 0.130 & & & 0.006 \\
\hline $\mathrm{P}_{23}$ & & 0.156 & & & 0.008 \\
\hline $\mathrm{P}_{24}$ & & 0.165 & & & 0.008 \\
\hline $\mathrm{P}_{25}$ & & 0.493 & & & 0.024 \\
\hline $\mathrm{P}_{31}$ & & & 0.050 & & 0.030 \\
\hline
\end{tabular}




\begin{tabular}{|l|l|l|l|l|l|}
\hline $\mathrm{P}_{32}$ & & & 0.410 & & 0.244 \\
\hline $\mathrm{P}_{33}$ & & & 0.225 & & 0.134 \\
\hline $\mathrm{P}_{34}$ & & & 0.193 & & 0.115 \\
\hline $\mathrm{P}_{35}$ & & & 0.122 & & 0.073 \\
\hline $\mathrm{P}_{41}$ & & & & 0.107 & 0.027 \\
\hline $\mathrm{P}_{42}$ & & & & 0.061 & 0.015 \\
\hline $\mathrm{P}_{43}$ & & & & 0.361 & 0.090 \\
\hline $\mathrm{P}_{44}$ & & & & 0.321 & 0.080 \\
\hline $\mathrm{P}_{45}$ & & & & 0.150 & 0.037 \\
\hline
\end{tabular}

\subsection{Determine the Grey Clustering of Computer Network Security Risk Evaluation}

According to the risk degree of computer network security, whether or not to take the necessary measures, combined with some opinions of computer network security experts, computer network security risk can be divided into four levels, that is, level 1 , level 2 , level 3, and level 4. And there are four corresponding evaluation grey classes, namely, grey classification $k=1,2,3,4$, the corresponding level description of computer network security risk is shown in Table 3.

Table 3. The Risk Level Classification Standards of Computer Network Security

\begin{tabular}{|l|l|}
\hline $\begin{array}{l}\text { Risk } \\
\text { level }\end{array}$ & \multicolumn{1}{c|}{ Classification standards } \\
\hline Level 1 & $\begin{array}{l}\text { The risk level of computer network security can be accepted. The current } \\
\text { computer network is safe, and the preventive measures are appropriate. }\end{array}$ \\
\hline Level 2 & $\begin{array}{l}\text { Computer network security risk level is accepted in certain conditions. The } \\
\text { current computer network is safe, most countermeasures are effective, but further } \\
\text { preventive measures should be taken in order to ensure safety. }\end{array}$ \\
\hline Level 3 & $\begin{array}{l}\text { Computer network security risk level is accepted in certain conditions. The } \\
\text { countermeasures of current computer network are poor; certain preventive } \\
\text { measures must be taken. And the corresponding emergency plan should be made. }\end{array}$ \\
\hline Level 4 & $\begin{array}{l}\text { Computer network security risk level is not acceptable; the current } \\
\text { countermeasures are poor. The necessary measures must be taken to reduce the } \\
\text { risk level into Level III or under it. }\end{array}$ \\
\hline
\end{tabular}

According to the computer network security risk guidelines and the index parameters of computer network technology, combined with the basic requirements of computer network security, consulting the relevant experts of computer network, referring to the related literature, Delphi method is used to get the grey number of four grey classes of computer network security risk evaluation clustering index. The details are shown in Table 4.

\section{Table 4. The Grey Number of Four Grey Classes of Computer Network} Security Risk Evaluation Clustering Index

\begin{tabular}{|c|c|c|c|c|c|}
\hline index & weight & Level I & Level II & Level III & Level IV \\
\hline $\mathrm{P}_{11}$ & 0.046 & $18 \leq \mathrm{P}_{11}<22$ & $22 \leq \mathrm{P}_{11}<27$ & $27 \leq \mathrm{P}_{11}<34$ & $34 \leq \mathrm{P}_{11}<41$ \\
\hline $\mathrm{P}_{12}$ & 0.007 & $30 \leq \mathrm{P}_{12}<40$ & $40 \leq \mathrm{P}_{12}<50$ & $50 \leq \mathrm{P}_{12}<75$ & $75 \leq \mathrm{P}_{12}<85$ \\
\hline $\mathrm{P}_{13}$ & 0.016 & $21 \leq \mathrm{P}_{13}<32$ & $32 \leq \mathrm{P}_{13}<38$ & $38 \leq \mathrm{P}_{13}<44$ & $44 \leq \mathrm{P}_{13}<52$ \\
\hline $\mathrm{P}_{14}$ & 0.010 & $14 \leq \mathrm{P}_{14}<22$ & $22 \leq \mathrm{P}_{14}<27$ & $27 \leq \mathrm{P}_{14}<34$ & $34 \leq \mathrm{P}_{14}<40$ \\
\hline $\mathrm{P}_{15}$ & 0.029 & $0 \leq \mathrm{P}_{15}<7$ & $7 \leq \mathrm{P}_{15}<15$ & $15 \leq \mathrm{P}_{15}<22$ & $22 \leq \mathrm{P}_{15}<28$ \\
\hline $\mathrm{P}_{21}$ & 0.003 & $12 \leq \mathrm{P}_{21}<22$ & $22 \leq \mathrm{P}_{21}<28$ & $28 \leq \mathrm{P}_{21}<34$ & $34 \leq \mathrm{P}_{21}<42$ \\
\hline
\end{tabular}




\begin{tabular}{|c|c|c|c|c|c|}
\hline $\mathrm{P}_{22}$ & 0.006 & $6 \leq \mathrm{P}_{22}<12$ & $12 \leq \mathrm{P}_{22}<17$ & $17 \leq \mathrm{P}_{22}<24$ & $24 \leq \mathrm{P}_{22}<30$ \\
\hline $\mathrm{P}_{23}$ & 0.008 & $40 \leq \mathrm{P}_{23}<50$ & $50 \leq \mathrm{P}_{23}<60$ & $60 \leq \mathrm{P}_{23}<70$ & $70 \leq \mathrm{P}_{23}<80$ \\
\hline $\mathrm{P}_{24}$ & 0.008 & $24 \leq \mathrm{P}_{24}<29$ & $29 \leq \mathrm{P}_{24}<36$ & $36 \leq \mathrm{P}_{24}<44$ & $44 \leq \mathrm{P}_{24}<52$ \\
\hline $\mathrm{P}_{25}$ & 0.024 & $8 \leq \mathrm{P}_{25}<12$ & $12 \leq \mathrm{P}_{25}<16$ & $16 \leq \mathrm{P}_{25}<24$ & $24 \leq \mathrm{P}_{25}<32$ \\
\hline $\mathrm{P}_{31}$ & 0.030 & $20 \leq \mathrm{P}_{31}<25$ & $25 \leq \mathrm{P}_{31}<30$ & $30 \leq \mathrm{P}_{31}<38$ & $38 \leq \mathrm{P}_{31}<44$ \\
\hline $\mathrm{P}_{32}$ & 0.244 & $15 \leq \mathrm{P}_{32}<20$ & $20 \leq \mathrm{P}_{32}<24$ & $24 \leq \mathrm{P}_{32}<30$ & $30 \leq \mathrm{P}_{32}<40$ \\
\hline $\mathrm{P}_{33}$ & 0.134 & $13 \leq \mathrm{P}_{33}<17$ & $17 \leq \mathrm{P}_{33}<22$ & $22 \leq \mathrm{P}_{33}<26$ & $26 \leq \mathrm{P}_{33}<33$ \\
\hline $\mathrm{P}_{34}$ & 0.115 & $24 \leq \mathrm{P}_{34}<30$ & $30 \leq \mathrm{P}_{34}<35$ & $35 \leq \mathrm{P}_{34}<41$ & $41 \leq \mathrm{P}_{34}<50$ \\
\hline $\mathrm{P}_{35}$ & 0.073 & $6 \leq \mathrm{P}_{35}<9$ & $9 \leq \mathrm{P}_{35}<13$ & $13 \leq \mathrm{P}_{35}<18$ & $18 \leq \mathrm{P}_{35}<24$ \\
\hline $\mathrm{P}_{41}$ & 0.027 & $10 \leq \mathrm{P}_{41}<15$ & $15 \leq \mathrm{P}_{41}<20$ & $20 \leq \mathrm{P}_{41}<25$ & $25 \leq \mathrm{P}_{41}<30$ \\
\hline $\mathrm{P}_{42}$ & 0.015 & $5 \leq \mathrm{P}_{42}<9$ & $9 \leq \mathrm{P}_{42}<14$ & $14 \leq \mathrm{P}_{42}<20$ & $20 \leq \mathrm{P}_{42}<23$ \\
\hline $\mathrm{P}_{43}$ & 0.090 & $3 \leq \mathrm{P}_{43}<8$ & $8 \leq \mathrm{P}_{43}<12$ & $12 \leq \mathrm{P}_{43}<18$ & $18 \leq \mathrm{P}_{43}<22$ \\
\hline $\mathrm{P}_{44}$ & 0.080 & $11 \leq \mathrm{P}_{44}<17$ & $17 \leq \mathrm{P}_{44}<22$ & $22 \leq \mathrm{P}_{44}<25$ & $25 \leq \mathrm{P}_{44}<30$ \\
\hline $\mathrm{P}_{45}$ & 0.037 & $4 \leq \mathrm{P}_{45}<10$ & $10 \leq \mathrm{P}_{45}<14$ & $14 \leq \mathrm{P}_{45}<20$ & $20 \leq \mathrm{P}_{45}<25$ \\
\hline
\end{tabular}

\subsection{Establish the Whitenization Weight Function of Computer Network Security Risk Evaluation Model, and Calculate its Function Value.}

Grey clustering method is on the basis of analyzing different clustering objects, calculating the whitenization weight function of different index objects, and then synthesizing all index weights to calculate grey clustering number, so as to carry out the inductive research on all indexes according to different grey number. Which clustering type of the objects belongs to has great relationship with the impact of these indexes to the clustering objects. The clustering objects in this paper are the four risk sources of computer network, and the clustering indexes are the corresponding risk evaluation indexes of computer network security of these four risk sources. Here we choose the grey evaluation method of whitenization weight function based on endpoint triangular.

let

$$
f_{i}^{k}\left(x_{i}\right)=\left\{\begin{array}{cc}
0, & x_{i} \notin\left[a_{k-1}, a_{k+2}\right] \\
\frac{x_{i}-a_{k-1}}{\lambda_{k}-a_{k-1}}, & x_{i} \in\left[a_{k-1}, \lambda_{k}\right] \\
\frac{a_{k+2}-x_{i}}{a_{k+2}-\lambda_{k}}, & x_{i} \in\left[\lambda_{k}, a_{k+2}\right]
\end{array}\right.
$$

$x_{i}$ is the scoring value of index ${ }^{i}, k$ represents its evaluation grey classification.

Substitute the scoring value ${ }^{x_{i}}$ of the experts giving to computer network security risk evaluation index into the formula (1), the triangle whiten function $f_{i}^{k}\left(x_{i}\right)$ of the four grey classes of each computer network risk evaluation index, and $\lambda_{k}=\frac{a_{k}+a_{k+1}}{2}, a_{0}=a_{1}-5, a_{6}=a_{5}+5$. 


\subsection{Calculate the Whitenization Weight Clustering Coefficient and the Clustering Vector of Computer Network Security Risk Evaluation Model.}

The formula

$\sigma_{i}^{k}=\sum_{i=1}^{m} f_{i}^{k}\left(x_{i}\right) W_{i}$

is the gray variable comprehensive clustering coefficient of $k$ grey class. And $x_{i}$ is the evaluation value of computer network security risk evaluation indexes, $f_{i}^{k}\left(x_{i}\right)$ is the whitenization weight function of $k$ subclass of index $i . W_{i}$ is the weight of index $i$ among the comprehensive clustering.

Using the formula (2), software MATLAB is used to calculate the comprehensive clustering coefficient of each grey class, and the clustering coefficient set of clustering objects could be obtained as $\left(\sigma_{i}^{1}, \sigma_{i}^{2}, \sigma_{i}^{3}, \sigma_{i}^{4}\right)$, according to the maximum membership principle to judge the clustering degree of clustering objects.

\section{The Simulation Calculation of Computer Network Security Risk Evaluation Model}

According to the four grey number of computer network security risk evaluation clustering index above, combined with the risk score the five computer network security experts give to the 20 second-level indexes of evaluation model, the grey class scoring table of computer network security risk evaluation of Weifang University of Science and Technology could be obtained. The details are shown in Table 5 .

Table 5. The Grey Class Scoring Table of Computer Network Security Risk Evaluation of Weifang University of Science and Technology

\begin{tabular}{|c|c|c|c|c|c|c|}
\hline $\begin{array}{c}\text { Inde } \\
\mathrm{x}\end{array}$ & expert 1 & $\begin{array}{c}\text { expert } \\
2\end{array}$ & $\begin{array}{c}\text { expert } \\
3\end{array}$ & $\begin{array}{c}\text { expert } \\
4\end{array}$ & $\begin{array}{c}\text { expert } \\
5\end{array}$ & $\begin{array}{c}\text { average } \\
\text { mark } x_{i j}\end{array}$ \\
\hline $\mathrm{P}_{11}$ & 36 & 32 & 27 & 24 & 28 & 29 \\
\hline $\mathrm{P}_{12}$ & 65 & 48 & 58 & 42 & 54 & 53 \\
\hline $\mathrm{P}_{13}$ & 46 & 42 & 28 & 30 & 34 & 36 \\
\hline $\mathrm{P}_{14}$ & 14 & 16 & 11 & 16 & 18 & 21 \\
\hline $\mathrm{P}_{15}$ & 18 & 22 & 14 & 8 & 12 & 15 \\
\hline $\mathrm{P}_{21}$ & 14 & 25 & 23 & 16 & 18 & 19 \\
\hline $\mathrm{P}_{22}$ & 18 & 16 & 21 & 15 & 23 & 19 \\
\hline $\mathrm{P}_{23}$ & 68 & 44 & 72 & 48 & 64 & 59 \\
\hline $\mathrm{P}_{24}$ & 39 & 37 & 24 & 28 & 33 & 32 \\
\hline $\mathrm{P}_{25}$ & 26 & 28 & 16 & 18 & 19 & 21 \\
\hline $\mathrm{P}_{31}$ & 38 & 44 & 40 & 36 & 42 & 40 \\
\hline $\mathrm{P}_{32}$ & 32 & 21 & 38 & 25 & 30 & 29 \\
\hline $\mathrm{P}_{33}$ & 12 & 13 & 11 & 11 & 15 & 12 \\
\hline $\mathrm{P}_{34}$ & 52 & 48 & 56 & 46 & 54 & 51 \\
\hline $\mathrm{P}_{35}$ & 9 & 12 & 7 & 8 & 10 & 9 \\
\hline $\mathrm{P}_{41}$ & 18 & 26 & 20 & 19 & 21 & 21 \\
\hline $\mathrm{P}_{42}$ & 14 & 9 & 10 & 8 & 13 & 11 \\
\hline $\mathrm{P}_{43}$ & 10 & 12 & 8 & 4 & 9 & 9 \\
\hline $\mathrm{P}_{44}$ & 26 & 31 & 28 & 25 & 24 & 27 \\
\hline $\mathrm{P}_{45}$ & 14 & 15 & 13 & 11 & 18 & 14 \\
\hline & & & & & & \\
\hline
\end{tabular}


Substitute the average value $x_{i j}$ of five computer network security experts scoring in table 5 into formula (1), we could get 4 corresponding grey whitenization weight function of 20 second-level evaluation indexes, the whitenization weight function value of computer network security risk index of Weifang University of Science and Technology could be got. The specific details are shown in Table 6 .

\section{Table 6. The Whitenization Weight Function Value Table of Computer Network Security Risk Index of Weifang University of Science and Technology}

\begin{tabular}{|c|c|c|c|c|c|}
\hline Index & average mark $x_{i j}$ & $f_{i}^{1}\left(x_{i j}\right)$ & $f_{i}^{2}\left(x_{i j}\right)$ & $f_{i}^{3}\left(x_{i j}\right)$ & $f_{i}^{4}\left(x_{i j}\right)$ \\
\hline $\mathrm{P}_{11}$ & 29 & 0.0000 & 0.5236 & 0.8235 & 0.1905 \\
\hline $\mathrm{P}_{12}$ & 53 & 0.0000 & 0.7333 & 0.5778 & 0.1000 \\
\hline $\mathrm{P}_{13}$ & 36 & 0.1739 & 0.8889 & 0.6667 & 0.0000 \\
\hline $\mathrm{P}_{14}$ & 21 & 0.6667 & 0.6667 & 0.0000 & 0.0000 \\
\hline $\mathrm{P}_{15}$ & 15 & 0.0000 & 0.6364 & 0.6957 & 0.0000 \\
\hline $\mathrm{P}_{21}$ & 19 & 0.8182 & 0.5385 & 0.0000 & 0.0000 \\
\hline $\mathrm{P}_{22}$ & 19 & 0.0000 & 0.5236 & 0.8235 & 0.2000 \\
\hline $\mathrm{P}_{23}$ & 59 & 0.0667 & 0.7333 & 0.6000 & 0.0000 \\
\hline $\mathrm{P}_{24}$ & 32 & 0.4211 & 0.9412 & 0.2727 & 0.0000 \\
\hline $\mathrm{P}_{25}$ & 21 & 0.0000 & 0.3000 & 0.9167 & 0.4167 \\
\hline $\mathrm{P}_{31}$ & 40 & 0.0000 & 0.0000 & 0.4000 & 0.9091 \\
\hline $\mathrm{P}_{32}$ & 29 & 0.0000 & 0.1250 & 0.8462 & 0.4545 \\
\hline $\mathrm{P}_{33}$ & 12 & 0.5714 & 0.0000 & 0.0000 & 0.0000 \\
\hline $\mathrm{P}_{34}$ & 51 & 0.0000 & 0.0000 & 0.0000 & 0.4211 \\
\hline $\mathrm{P}_{35}$ & 9 & 0.7273 & 0.6000 & 0.0000 & 0.0000 \\
\hline $\mathrm{P}_{41}$ & 21 & 0.0000 & 0.5333 & 0.8000 & 0.1333 \\
\hline $\mathrm{P}_{42}$ & 11 & 0.4286 & 0.9231 & 0.2857 & 0.0000 \\
\hline $\mathrm{P}_{43}$ & 9 & 0.4615 & 0.8517 & 0.1429 & 0.0000 \\
\hline $\mathrm{P}_{44}$ & 27 & 0.0000 & 0.0000 & 0.4615 & 0.9090 \\
\hline $\mathrm{P}_{45}$ & 14 & 0.0000 & 0.7500 & 0.5714 & 0.0000 \\
\hline
\end{tabular}

By the formula (2), MATLAB software is used to calculate the comprehensive clustering coefficient $\sigma_{i}^{k}$ of four gray classifications of computer network of Weifang University of Science and Technology. The specific details are shown in Table 7.

Table 7. The Comprehensive Clustering Coefficient of Computer Network Security Risk of Weifang University of Science and Technology

\begin{tabular}{|c|c|c|c|c|c|}
\hline \multirow{2}{*}{ grey classification } & \multicolumn{4}{|c|}{ Clustering index } & \multirow{2}{*}{ total } \\
\cline { 2 - 5 } & $\mathrm{P}_{1}$ & $\mathrm{P}_{2}$ & $\mathrm{P}_{3}$ & $\mathrm{P}_{4}$ & \multirow{2}{*}{0.1602} \\
\hline \multirow{2}{*}{ Level I } & $\begin{array}{c}0.009 \\
4\end{array}$ & $\begin{array}{c}0.068 \\
6\end{array}$ & $\begin{array}{c}0.072 \\
8\end{array}$ & $\begin{array}{c}0.009 \\
5\end{array}$ & \multirow{2}{*}{0.0768} \\
\hline \multirow{2}{*}{ Level II } & $\begin{array}{c}0.006 \\
4\end{array}$ & $\begin{array}{c}0.025 \\
4\end{array}$ & $\begin{array}{c}0.033 \\
9\end{array}$ & $\begin{array}{c}0.011 \\
2\end{array}$ & \multirow{2}{*}{0.6090} \\
\hline \multirow{2}{*}{ Level III } & $\begin{array}{c}0.129 \\
7\end{array}$ & $\begin{array}{c}0.074 \\
3\end{array}$ & $\begin{array}{c}0.218 \\
5\end{array}$ & $\begin{array}{c}0.186 \\
6\end{array}$ & \multirow{2}{*}{0.3537} \\
\hline \multirow{2}{*}{ Level IV } & $\begin{array}{c}0.048 \\
0\end{array}$ & $\begin{array}{c}0.132 \\
6\end{array}$ & $\begin{array}{c}0.096 \\
8\end{array}$ & $\begin{array}{c}0.076 \\
3\end{array}$ & 0.3 \\
\hline
\end{tabular}


From Table 7 we could get that $\sigma^{1}=0.1602, \sigma^{2}=0.0768, \sigma^{3}=0.6090, \sigma^{4}=0.3537$, the possibility of the four computer network grey clustering of Weifang University of Science and Technology is $\sigma^{3}>\sigma^{4}>\sigma^{1}>\sigma^{2}$. According to the maximum membership degree principle, the overall risk level of computer network of Weifang University of Science and Technology is level 3.

\section{Conclusion}

The risk evaluation of computer network security is a hot issue. On the premise of comprehensive consideration on the influencing factors of computer network security, selecting 4 first-level indexes and 20 second-level indexes, the grey clustering evaluation model of computer network security risk is established. This model is reasonable and feasible.

\section{References}

[1] Chen, "Based on fuzzy hierarchy analysis method for large bridge project risk assessment [J]", Journal of shijiazhuang railway university, (2010), vol. 23, no. 3, pp. 29-33.

[2] L. Bo, the Netherlands, "Network security evaluation method based on bayesian networks is studied", Computer engineering, vol. 11, (2004), pp. 111.

[3] H.-L. Li and Z. Q. Li, "Based on grey clustering method of green construction assessment [J]", Journal of engineering management, vol. 26, no. 2, (2012), pp. 18-22.

[4] F.-Y. Dong, X. MeiDan, L. Bin and H. Ying, "The structure of the whitenization weight function of the teaching of the grey system analysis [J]", Journal of north China institute of water conservancy and hydropower, no. 3, (2010), pp. 97-99.

[5] H. Yin and L. Baihang, "Based on ANP - grey clustering analysis of comprehensive high-tech achievements transformation value evaluation [J]", Journal of management and administration, no. 18, (2009), pp. 107-115.

[6] Nelson and N.-M. Xie, "Based on the improved triangular whitenization weight function of grey evaluating new method [J]", Journal of systems engineering, vol. 26, no. 2, (2011), pp. 244-250.

[7] D. Ran, "Grey whitenization weight function of the triangle in the evaluation of water conservancy engineering after application [J]", Science and technology, BBS, no. 7, (2009), pp. 22-24.

[8] is filled again, dream, T.-B. Zhang and L. Zhenguo, "Based on the fuzzy neural network under the complex environment of military container, the optimal transportation plan selection [J]", Port \&waterway engineering, no. 6, (2012), pp. 63-68.

[9] Li Hui, "The network information security technology", Zte technology, (2004).

[10] "IBM technical support center in China", The IT system security, the white paper, (2004), 12.

[11] QuCheng righteousness and X.-H. Chen, "The concept of information system security evaluation research", The information security and communications confidential, vol. 9, (2003), p. 17.

[12] L. Tienan and L. Jinglei, "The application of multilevel fuzzy comprehensive evaluation method research", Journal of Harbin engineering university, vol. 5, (2002), p. 36.

[13] S. Ping, class ii and Q.-K. Peng, "A computer network information security model and application", Xi 'an jiaotong university, (2003), 5.

[14] J. Rui and P. L. Colton, "The new network information system security model and its mathematical evaluation", Computer engineering, vol. 7, (2005), p. 141.

[15] Zheng is bright, "The network information security evaluation model based on grey theory research", Nanjing information engineering university, vol. 5, (2005), p. 38.

[16] C. Circle, "The computer network system security analysis and assessment", Zhengzhou university. vol. 5, (2002), p. 23. 
International Journal of Security and Its Applications

Vol. 10, No. 8 (2016) 